\title{
PERENCANAAN IMPLEMENTASI MANAJEMEN PENGETAHUAN DI PERPUSTAKAAN PERGURUAN TINGGI BERBASIS TEKNOLOGI INFORMASI DAN KOMUNIKASI (TIK)
}

(Studi Kasus di Perpustakaan IPDN Jatinangor Sumedang Jawa Barat)

\author{
Maryati, D. $S^{1}$, Wasliman ${ }^{2}$, Mudrikah, $A^{3}$, Sauri, $S^{4}$ \\ Universitas Islam Nusantara \\ delis.sri.maryati@gmail.com
}

\begin{abstract}
ABSTRAK
Penelitian ini dilatar belakangi oleh perlu adanya implementasi manajemen pengetahuan di perpustakaan Perguruan Tinggi yang berbasis teknologi informasi dan komunikasi agar pengetahuan dapat diakses secara efektif dan efisien untuk diketahui, dipelajari, digunakan kembali, penelitian dan publikasi ilmiah. Tujuan penelitian ini adalah untuk memperoleh gambaran dan menganalisis tentang Implementasi Manajemen Pengetahuan (knowledge management) Perpustakaan Perguruan Tinggi berbasis Teknologi Informasi dan Komunikasi dalam hal Pelayanan Prima Tenaga Perpustakaan Perpustakaan IPDN Jatinangor Sumedang Jawa Barat. Penelitian ini menggunakan penelitian kualitatif dengan pendekatan deskriptif. Teknik pengumpulan data melalui observasi, wawancara dan studi dokumentasi. Teori dalam penelitian ini adalah teori Manajemen menurut Hasibuan, M (2017:10), Mangkunegara, A (2017:2), teori Pengetahuan Davenport \& Prusak (1998:42) dan Implementasi Manajemen Pengetahuan menurut Bhatt, D (2000). Hasil penelitian ini adalah: Perencanaan tenaga perpustakaan IPDN Jatinangor dari segi rekruitmen, pendidikan, pengembangan, motivasi, retensi, kerjasama dan partisipasi seluruh pegawai (share knowledge to creating value through social interaction) sudah dilakukan meskipun belum maksimal, karena pustakawan bagian IT jumlahnya masih sedikit dan tenaga teknis IT juga belum ada ahlinya, sehingga pengelolaan website masih bekerjasama dengan unit lain di IPDN. Perencanaan proses pengadaan pengetahuan dan teknologi di perpustakaan IPDN telah dilakukan oleh tenaga perpustakaan IPDN, walaupun tidak semua terealisasi karena keterbatasan anggaran.

Kata Kunci: Manajemen, Implementasi Manajemen Pengetahuan
\end{abstract}

\begin{abstract}
This research is motivated by the need for the implementation of knowledge management in higher education libraries based on information and communication technology so that knowledge can be accessed effectively and efficiently to be known, studied, reused, research and scientific publications. The general objective of this study is to obtain an overview and analysis of the implementation of knowledge management in the Information and Communication Technology-based University Libraries in terms of excellent service to the library personnel of IPDN Jatinangor Library, Sumedang West Java. Specific objectives are to determine the planning, organization, implementation, supervision, development, and partnerships plus supporting and inhibiting factors as well as the results of the implementation of information and communication technology-based library knowledge management for Higher Education (ICT) libraries (descriptive analysis of excellent service for Jatinangor Sumedang IPDN librarian). This research uses qualitative research with a descriptive approach. Data collection techniques through observation, interviews and documentation study. Theories in this study are Management theory according to Hasibuan, M (2017: 10), Mangkunegara, A (2017: 2), Davenport \& Prusak's Knowledge theory (1998: 42) and Knowledge Management Implementation according to Bhatt, D (2000). The results of this study are: Planning for IPDN Jatinangor library staff in terms of recruitment, education,
\end{abstract}

\footnotetext{
${ }^{1}$ Mahasiswa Pascasarjana S3 IImu Pendidikan UNINUS Bandung

${ }^{2}$ Dosen Pascasarjana UNINUS Bandung

${ }^{3}$ Dosen UNINUS Bandung

${ }^{4}$ Dosen UNINUS Bandung
} 
development, motivation, retention, cooperation and participation of all employees (share knowledge to create value through social interaction) has been carried out, although not yet optimal, because the number of librarians in IT there are still few and IT technical personnel are also not experts, so the management of the website is still in collaboration with other units in IPDN. The IPDN library staff had planned the process of procuring knowledge and technology in the IPDN library, although not all of it was realized due to budget constraints.

Keywords: Management, Knowledge Management Implementation 


\section{PENDAHULUAN}

Implementasi manajemen pengetahuan (knowledge management) di Perguruan Tinggi bermanfaat sebagai pendekatan yang terencana dan juga sistematis agar menjamin penerapan pengetahuan organisasi yang baik, sekaligus meningkatkan gagasan, inovasi, pemikiran, kompetensi dan keahlian serta meningkatkan layanan pada pelanggan. Hal ini sejalan dengan Dalkir K (2005) bahwa:

'Dalam implementasi manajemen pengetahuan (knowledge management) baik di sektor bisnis maupun institusi pendidikan tentu tidak terlepas dari 3 komponen yaitu: people, procces, dan technology. Dalam konteks implementasi manajemen pengetahuan (knowledge management): organisasi memberdayakan sumber daya manusia (people) untuk knowledge management dan sharing knowledge'.

Perkembangan ilmu pengetahuan dan teknologi yang sangat pesat saat ini, telah membawa perubahan yang sangat pesat pula dalam berbagai aspek kehidupan. Pekerjaan dan cara kita bekerja berubah, banyak lapangan pekerjaan hilang, sementara berbagai jenis pekerjaan baru bermunculan. Perubahan ekonomi, sosial, dan budaya juga terjadi dengan laju yang tinggi. Dalam masa yang sangat dinamis ini, Perguruan Tinggi harus merespon secara cepat dan tepat. Diperlukan transformasi pembelajaran untuk bisa membekali dan menyiapkan lulusan Pendidikan Tinggi agar menjadi generasi yang unggul, generasi yang tanggap dan siap menghadapi tantangan zamannya, tanpa tercerabut dari akar budaya bangsanya.

Saat ini kreativitas dan inovasi menjadi kata kunci penting untuk memastikan pembangunan Indonesia yang berkelanjutan. Para mahasiswa yang saat ini belajar di Perguruan Tinggi, harus disiapkan menjadi pembelajar yang terampil, lentur dan ulet (agile learner). Dengan adanya Kebijakan Merdeka Belajar Kampus Merdeka yang diluncurkan oleh Menteri Pendidikan dan Kebudayaan pada tahun 2020 untuk menyiapkan mahasiswa menjadi sarjana yang tangguh, relevan dengan kebutuhan zaman, dan siap menjadi pemimpin dengan semangat kebangsaan yang tinggi.

Oleh sebab itu, pada saat ini paradigma baru Perguruan Tinggi terjadi perubahan yang sangat signifikan. Begitu juga dengan perpustakaan perguruan tinggi pun harus mengikuti perubahan tersebut yaitu dengan kecanggihan teknologi civitas kampus baik itu mahasiswa, dosen, maupun peneliti bisa dengan mudah mengakses pengetahuan baik dari dalam maupun luar negeri secara cepat dan kapan pun hanya dari gadget masing-masing. Oleh sebab itu, implementasi menajemen pengetahuan di Perguruan Tinggi merupakan suatu kebutuhan dan hal penting untuk kelangsungan pengetahuan agar dapat digali dan disebarluaskan kepada para pencari pengetahuan.

Kebijakan yang terkait dengan manajemen pengetahuan di Perguruan Tinggi sangatlah penting dintegrasikan dengan visi dan misi Perguruan Tinggi dalam menghadapai era masyarakat berbasis pengetahuan (knowledge based society) yang diarahkan untuk mampu membangun dan menjalankan semangat belajar, khususnya dalam menjalankan program pendidikan, penelitian maupun pengabdian kepada masyarakat.

Pemerintah telah mengeluarkan Peraturan Menteri Riset, Teknologi dan Pendidikan Tinggi Republik Indonesia Nomor 9 Tahun 2018 tentang Akreditasi Jurnal Ilmiah untuk meningkatkan relevansi, kuantitas dan kualitas publikasi ilmiah ilmuan Indonesia untuk mendukung daya saing bangsa di tingkat internasional. Dalam Pasal 1 disebutkan bahwa: 'Jurnal ilmiah adalah bentuk pemberitaan atau komunikasi yang memuat karya ilmiah dan diterbitkan berjadwal dalam bentuk elektronik dan cetak'. Untuk mencapai hal tersebut tentunya harus ada tempat di Perguruan Tinggi yang menaungi jurnal ilmiah.

Selajutnya, ada juga Undang-undang RI Nomor 13 tahun 2018 tentang Serah Simpan Karya Cetak dan Karya Rekam sebagai perlindungan seluruh aset budaya bangsa yang terdokumentasi dalam karya cetak dan karya rekam yang bernilai intelektual dan atau artistik sebagai hasil karya bangsa Indonesia.

Tentunya dengan adanya perpustakaan Perguruan Tinggi yang merupakan "Bagian integral dari kegiatan pendidikan, penelitian dan pengabdian masyarakat dan berfungsi sebagai pusat belajar untuk mendukung tercapainya tujuan pendidikan yang berkedudukan di Perguruan Tinggi” (Peraturan Kepala Perpustakaan Nasional Republik Indonesia Nomor 13 tahun 2017). Perpustakaan sebagai pusat literasi informasi dan pusat kegiatan dapat menjadi wahana belajar sepanjang hayat untuk mengembangkan potensi seluruh civitas akademika.

Kebijakan dalam rangka pembangunan perpustakaan juga terdapat dalam Peraturan 
Presiden RI No. 72 tentang Rencana Kerja Pemerintah Tahun 2019:

'Pemerataan Pembangunan untuk Mengembangkan transformasi pelayanan perpustakaan b). Peningkatan akses literasi informasi c). Pendampingan untuk literasi informasi d). Peningkatan Penyatuan/penyimpanan teknologi informasi dan komunikasi dan komunikasi e). Penguatan kerja sama dan jejaring perpustakaan dengan berbagai lembaga pemerintah, dunia usaha dan masyarakat f). Penyatuan/penyimpanan sumber pendanaan secara efektif untuk peningkatan kualitas pelayanan perpustakaan'.

Menurut Hendrawan (2019:2), disebutkan bahwa:

'Penerapan teknologi informasi dan komunikasi dalam kerangka tata kelola informasi yang baik, akan memudahkan organisasi dalam strategi manajemen pengetahuan sebagai tujuan penguatan prinsip-prinsip dan praktik terbaik integrasi solusi di setiap masalah Penyatuan/penyimpanan informasi untuk memenuhi kebutuhan organisasi dan kebutuhan pengguna'.

Teknologi Informasi dan Komunikasi (TIK) menjadi hal yang penting sebagai sarana untuk menghasilkan keuntungan Perguruan Tinggi. TIK secara fundamental akan mengubah model bisnis dan penelitian Perguruan Tinggi. Tantangan-tantangan inilah yang mendorong munculnya kebutuhan terhadap implementasi manajemen pengetahuan (knowledge management) di Perguruan Tinggi.

Hal tersebut juga bertujuan untuk menyeimbangkan komitmen organisasi terhadap keterbukaan dan transparansi dengan tanggung jawab yang efektif. Oleh sebab itu, kunci sukses implementasi manajemen pengetahuan/ knowledge management di lingkungan pendidikan perlu ditunjang oleh teknologi informasi dan komunikasi agar memudahkan budaya mengakses dan meningkatkan kualitas pengetahuan dan sharing knowledge yang bermuara peningkatan mutu dan daya saing organisasi. Dengan demikian, peranan teknologi informasi dan komunikasi dalam implementasi manajemen pengetahuan (knowledge management) sebagai sarana untuk mencapai kesuksesan organisasi.

Proses untuk berbagi pengetahuan (knowledge sharing) di Perguruan Tinggi terletak pada perpustakaan Perguruan Tinggi tersebut, karena perpustakaan merupakan tempat berbagai macam pengetahuan dan informasi. Oleh karena itu, perlu adanya implementasi manajemen pengetahuan di perpustakaan Perguruan Tinggi yang berbasis teknologi informasi dan komunikasi agar pengetahuan dapat diakses secara efektif dan efisien untuk diketahui, dipelajari, digunakan kembali, penelitian dan publikasi ilmiah.

Perpustakaan Perguruan Tinggi merupakan Unit Pelaksana Teknis dari sebuah Perguruan Tinggi untuk mendukung kegiatan CIVA. Perpustakaan ini menjadi sebuah lembaga informasi dalam kegiatan pendidikan, penelitian dan pengabdian kepada masyarakat yang dikenal dengan Tri Dharma Perguruan Tinggi. Semua aktivitas kegiatan belajar mengajar dalam Perguruan Tinggi sangat bergantung pada perpustakaan. Fungsi perpustakaan sebagai pusat informasi, edukasi, penunjang riset, rekreasi, publikasi, deposit dan interpretasi terus berkembang dan informasi dapat digali dari berbagai media, terutama media internet.

Perkembangan teknologi informasi dan komunikasi memberikan dampak dalam pengelolaan perpustakaan. Perpustakaan sebagai tempat mengelola informasi dan pengetahuan banyak memnafaatkan komputer dan internet untuk berbagai keperluan. Dalam Buku Pedoman Perpustakaan Perguruan Tinggi (2004:20) dinyatakan bahwa:

'Beberapa pertimbangan yang dapat diajukan mengapa perpustakaan harus memanfaatkan TIK antara lain yaitu : 1) jumlah dan mutu layanan perpustakaan, 2) tuntutan untuk menggunakan koleksi secara bersama, 3) kebutuhan untuk mengefektifkan tenaga 4) kebutuhan akan efisiensi waktu, 5) ragam informasi yang dikelola, dan 6) kebutuhan akan kecepatan layanan'.

Penggunaan Teknologi Informasi dan Komunikasi (TIK) sangat berhubungan dengan peran perpustakaan sebagai pelestarian dan penyebaran informasi ilmu pengetahuan yang berkembang seiring dengan kegiatan menulis, mencetak, serta pemenuhan kebutuhan masyarakat akan informasi. Kemajuan Teknologi Informasi dan Komunikasi (TIK) dari tahun ke tahun merupakan bukti bahwa manusia selalu berusaha mendapatkan cara yang mudah, cepat dan akurat dalam memenuhi kebutuhan hidupnya untuk dalam mengelola data menjadi informasi.

Ada beberapa kendala dan keterbatasan yang umumnya dihadapi oleh perpustakaan 
Perguruan Tinggi di Indonesia, diantaranya adalah : a) Kendala secara internal : (1). Jumlah, jenis dan mutu koleksi bahan pustaka, (2). Jumlah dan mutu sumber daya manusia, (3). Sarana dan prasarana, (4). Sumber pembiayaan, (5). Sosialisasi, (6). Perhatian dari instansi induk/ atasan, b) Kendala secara eksternal: (1). Minat dan budaya baca mahasiswa (pemustaka) yang umumnya masih relatif rendah, (2). Perhatian, respon, dan tanggapan mahasiswa yang masih terbatas, (3). Informasi dan akses ke perpustakaan masih terbatas. (4). Kesadaran tentang perlunya perpustakaan belum tumbuh dan belum berkembang secara baik.

Selain itu, tinjau dari segi sumber daya manusia (SDM) dalam hal ini tenaga perpustakaan: faktanya, pelayanan tenaga perpustakaan seringkali menjadi tolok ukur pemustaka dalam menilai kualitas perpustakaan, karena pada bagian tersebut sumber daya manusia langsung berinteraksi dengan pemustaka. Tenaga perpustakaan baik itu tenaga teknis perpustakaan maupun pustakawan sebagai orang yang bertanggung jawab atas terlaksananya pelayanan harus mengetahui hal tersebut.

Berdasarkan observasi awal, data dari tenaga perpustakaan IPDN (wawancara kepada pustakawan perpustakaan IPDN Jatinangor Sumedang, pada tanggal 24 April 2019, pukul 10.00 WIB) diketahui bahwa:

'Latar belakang pendidikan pustakawan berbeda-beda. Hanya sedikit pustakawan yang berlatar belakang pendidikan formal Ilmu Perpustakaan dan Informasi. Sedangkan yang lain menjadi pustakawan ada yang melalui jalur seminar dan workshop ilmu perpustakaan yang dilaksanakan di kampus IPDN ataupun kerjasama dengan Perpustakaan Nasional'.

Selain itu wawancara kepada Kepala perpustakaan IPDN Jatinangor Sumedang, pada tanggal 24 April 2019, pukul 11.00 WIB, menyatakan bahwa:

'Perbedaan latar pendidikan pustakawan, antara pustakawan yang berlatar belakang pendidikan Ilmu Perpustakaan dan Informasi dan non Ilmu Perpustakaan dan Informasi serta rendahnya kemampuan pustakawan untuk menggunakan teknologi dikhawatirkan menimbulkan gap/jenjang pengetahuan, sehingga menjadikan proses implementasi manajemen pengetahuan terhambat'.
Dari berbagai permasalah yang ada, tentunya membangun perpustakaan Perguruan Tinggi berbasis TIK bukan suatu pekerjaan yang mudah, apalagi jika menyangkut pembiayaan. Namun demikian, apabila berhasil membangun perpustakaan berbasis TIK secara baik, niscaya citra perpustakaan akan semakin meningkat. Citra yang baik harus diupayakan secara terus menerus, supaya perpustakaan dapat meningkatkan kepercayaan dari pihak-pihak yang berkepentingan terutama pihak pimpinan Perguruan Tinggi.

Berdasarkan permasalahan tersebut, maka penulis ingin mengetahui lebih mendalam tentang Perencanaan Implementasi Manajemen Pengetahuan di Perpustakaan Perguruan Tinggi berbasis Teknologi Informasi dan Komunikasi (TIK) Studi Kasus di Perpustakaan IPDN Jatinangor Sumedang).

\section{METODE PENELITIAN}

Penelitian ini dilaksanakan dengan menggunakan pendekatan kualitatif, karena secara umum penelitin ini bertujuan untuk memperoleh gambaran dan menganalisis tentang Implementasi Manajemen Pengetahuan (knowledge management) Perpustakaan Perguruan Tinggi berbasis Teknologi Informasi dan Komunikasi (TIK) (Studi Kasus di Perpustakaan IPDN Jatinangor Sumedang Jawa Barat). Teknik pengumpulan data menggunakan wawancara, studi doukumentasi dan observasi. Sumber data yang diperlukan dalam penelitian ini, peneliti mengklasifikasikan menjadi 3 tingkatan huruf $\mathrm{p}$ dari bahasa Inggris, yaitu:

Person: sumber data yang bisa memberikan data berupa jawaban lisan melalui wawancara. Dalam penelitian ini data diambil melalui wawancara kepada (Kepala perpustakaan, pustakawan bidang TIK, pustakawan pelayanan, tenaga teknik bidang TIK) di IPDN Jatinangor Sumedang Jawa Barat)

Place: sumber data yang menyajikan tampilan berupa keadaan tempat. Dalam penelitian ini, peneliti mengobservasi kegiatan implementasi manajemen pengetahuan di perpustakaan IPDN Jatinangor Sumedang Jawa Barat.

Paper: sumber data yang menyajikan data, dan gambar dari di perpustakaan IPDN Jatinangor Sumedang Jawa Barat.

\section{HASIL DAN PEMBAHASAN}

Perencanaan implementasi manajemen pengetahuan (knowledge management) 
perpustakaan Perguruan Tinggi berbasis Teknologi Infomasi Komunikasi (TIK) di perpustakaan IPDN Jatinangor Sumedang Jawa Barat adalah sebagai berikut:

Perpustakaan IPDN Jatinangor sebagai sebuah organisasi telah memiliki rencana startegis hal ini dilihat dari adanya statuta dan renstra lembaga, dengan adanya statuta lembaga, tenaga perpustakaan IPDN dapat merumuskan kegiatankegiatan yang diperlukan agar mencapai hasil yang diinginkan, sesuai dengan teori George Terry dalam Hasibuan, M (2017:249), yaitu:

"Planning is the selecting and relating of facts and the making and using of assumptions regarding the future in the visualization and formulation to proposed of proposed activation believed necesarry to accieve desired result".

(Perencanaan adalah memilih dan menghubungkan fakta dan membuat serta dan menggunaan asumsi-asumsi mengenai masa yang akan datang dengan jalan menggambarkan dan merumuskan kegiatan-kegiatan yang diperlukan untuk mencapai hasil yang diinginkan).

Dengan adanya Visi dan Misi Perpustakaan Institut Pemerintahan Dalam Negeri (IPDN), menurut Ya'qub, H (1984:61) dapat menentukan titik tolak dan tujuan usaha; memberikan pedoman, pegangan dan arah; mencegah pemborosan waktu; memudahkan pengawasan; memungkinkan evaluasi yang teratur; sebagai alat koordinasi, sehigga apa yang dinginkan organisasi jelas arahnya.

Selanjutnya dengan adanya Tujuan dan Fungsi Perpustakaan Institut Pemerintahan Dalam Negeri (IPDN) menjadi unsur-unsur penting dalam perencanaan sebagai "What: tindakan apa yang harus dibuat, why: apakah sebabnya jika tindakan itu harus dikerjakan, where: dimanakah tindakan itu akan dilaksanakan, when: kapankah dilaksanakannya, who: siapa yang akan mengerjakan, how: bagaimana cara melaksanakan".

Perencanaan dimulai dari renstra yang sifatnya jangka pendek, menengah dan panjang. Sesuai dengan jenis-jenis perencanaan menurut Ya'qub, H (1984:68), antara lain: perencanaan jangka waktu panjang (perencanaan yang membutuhkan waktu yang cukup lama dalam pelaksanaannya cukup lama, biasanya lebih dari tiga tahun), perencanaan jangka waktu sedang (pelaksanaannya satu-tiga tahun), perencanaan jangka waktu pendek (perencanaan yang pelaksanaanya dalam satu tahun/kurang dari satu tahun). Adapun komponen dari implementasi manajemen pengetahuan adalah sebagai berikut:

\section{1) SDM dalam implementasi manajemen pengetahuan (knowledge management)}

Sumber Daya Manusia di perpustakaan IPDN Jatinangor terdiri atas Kepala Unit Perpustakaan, pustakawan dan tenaga teknis perpustakaan. Kepala Unit Perpustakan IPDN sebagai pemimpin perpustakaan, bertugas di perpustakaan IPDN karena mendapat tugas dari kepegawaian IPDN sebagai tugas tambahan Dosen PNS untuk mengelola perpustakaan IPDN dan bertanggung jawab kepada Rektor melalui Wakil Rektor I. Tenaga perpustakaan yang teridiri atas pustakawan dan tenaga teknis perpustakaan, mereka mendapat tugas mengeloa perpustakaan IPDN Jatinangor berdasarkan SK dari kepegawaian IPDN baik yang berstatus PNS maupun honorer.

Perencanaan tenaga perpustakaan merupakan hal yang sangat penting, karena perpustakaan perguruan tinggi merupakan unit kerja yang melaksanakan Tri Dharma Perguruan Tinggi yaitu pendidikan, penelitian dan pengabdian masyarakat, sehingga perlu adanya pengelola yang mumpuni untuk menyediakan pengetahuan dan informasi bagi sivitas akademika sehingga pengetahuan yang ada di perguruan tinggi tersebut dapat diciptakan, digunakan dan disebarluaskan.

Perpustakaan Perguruan Tinggi sering dimaknai sebagai pusat penelitian karena banyak menyediakan informasi yang berkaitan dengan sarana pendukung dalam proses penelitian. Selaras dengan kegiatan perpustakaan Perguruan Tinggi, dalam Buku Pedoman Perpustakaan Perguruan Tinggi (2004:3) tujuan perpustakaan Perguruan Tinggi sebagai berikut:

1) Mengadakan buku, jurnal dan pustaka lainnya untuk dipakai oleh Dosen, mahasiswa dan staf lainnya bagi kelancaran program pengajaran di perpustakaan Perguruan Tinggi.

2) Mengadakan buku, jurnal dan pustaka lainnya yang diperlukan untuk penelitian sejauh dana tersedia.

3) Mengusahakan, menyimpan dan merawat pustaka yang bernilai sejarah, yang dihasilkan oleh sivitas akademik.

4) Menyediakan sarana bibliografi untuk menunjang pemakaian perpustakaan.

5) Menyediakan tenaga yang cukup serta penuh dedikasi untuk melayani 
kebutuhan pengguna perpustakaan dan bila perlu mampu memberikan pelatihan penggunaan perpustakaan.

6) Bekerja sama dengan perpustakaan lain untuk mengembangkan program perpustakaan.

Dipertegas dengan pendapat Sulistyo, B (2003) juga menyatakan tujuan penyelenggaraan perpustakaan Perguruan Tinggi adalah:

1) Memenuhi keperluan informasi masyarakat Perguruan Tinggi, lazimnya Dosen dan mahasiswa sering pula mencakup tenaga administrasi Perguruan Tinggi.

2) Menyediakan bahan pustaka rujukan (referensi) pada semua tingkat akademis, artinya mulai dari mahasiswa tahun pertama hingga kemahasiswa program pascasarjana dan pengajar.

3) Menyediakan ruang belajar untuk pemakai perpustakaan.

4) Menyediakan jasa peminjaman yang tepat guna bagi berbagai jenis pemakai.

5) Menyediakan jenis informasi aktif yang tidak hanya terbatas pada lingkungan perguruan tetapi juga lembaga induknya.

Semua kegiatan tersebut merupakan layanan yang ada di perpustakaan IPDN dan untuk menunjang hal tersebut, tentunya perlu adanya perencanaan tenaga perpustakaan agar pelayanan yang diberikan kepada pemustaka dapat dilaksanakan dengan baik.

Perencanaan tenaga perpustakaan IPDN diawali dengan rekruitmen kepala unit perpustakaan, tenaga perpustakaan baik untuk pustakawan maupun tenaga teknis perpustakaan Hal ini sejalan dengan pendapat Andrew E. Sikula dalam Mangkunegara, A (2017:4).

"Human resource of manpower planning has been defined as the process of determining manpower requirement and the means for meeting those requirements in order to carry out integrated plans of the organization. Andrew E. Sikula dalam Mangkunegara, A (2017:4).

(Perencanaan sumber daya manusia atau perencanaan tenaga kerja didefinisikan sebagai proses menentukan kebutuhan tenaga kerja dan berarti mempertemukan kebutuhan tersebut agar pelaksanaannya berintegrasi dengan rencana organisasi).

Berdasarkan teori tersebut dengan merencanakan sumber daya manusia untuk mengelola perpustakaan baik untuk kepala perpustakaan, pustakawan dan tenaga teknis perpustakaan diharapkan dapat memenuhi kebutuhan tenaga kerja agar pelaksanaan manajemen pengetahuan di perpustakaan IPDN terpenuhi.

Menurut Debowski dalam Hendrawan, $\mathrm{R}$ (2019:6): "Pengetahuan berada di dalam pemikiran seseorang dan akan ditransfer ke orang lain, sehingga sumber daya manusia adalah faktor utama dalam keberhasilan manajemen pengetahuan. Sumber daya manusia adalah yang memiliki knowledge, mengatur sistem dan proses, dan berkomitmen terhadap proses strategic knowledge untuk kesuksesan perusahaan". Oleh sebab itu Human resources (sumber daya manusia) merupakan komponen penting didalam proses Knowledge Management, dimana knowledge dan keahlian yang dimiliki oleh people akan menjadi value bagi organisasi tersebut.

Jika dilihat dari sudut pandang manajemen pengetahuan, hal ini sesuai dengan pendapat Debowski dalam Hendrawan (2019:7) mengenai bagian-bagian akitivitas management human resources (MSDM) yang memiliki dampak besar dalam Knowledge Management pada organisasi, yaitu:

a) Organisational Structure (struktur organisasi): SDM menganalisa terhadap struktur organisasi, proses hirarki organisasi, membuat keputusan, komunikasi dan inovasi.

b) Staffing: SDM menganalisa terhadap proses core competencies karyawan, proses seleksi dan rekruitmen dalam suatu organisasi. dalam hal ini kepegawaian juga menga

Kepala Unit Perpustakan IPDN bertugas di perpustakaan karena mendapat tugas dari kepegawaian IPDN sebagai tugas tambahan Dosen PNS di IPDN untuk mengelola perpustakaan IPDN. Kepala Unit Perpustakaan bertanggung jawab kepada Rektor melalui Wakil Rektor I. Selanjutnya mengenai rekruitmen tenaga perpustakaan yang teridiri atas pustakawan dan tenaga teknis perpustakaan, mereka mendapat tugas mengeloa perpustakaan IPDN Jatianangor berdasarkan SK dari kepegawaian IPDN baik yang berstatus PNS maupun honorer. Sejalan dengan pendapat Hasibuan, M (2017:250) "Perencanaan sumber daya manusia adalah merencanakan tenaga kerja agar sesuai dengan kebutuhan perusahaan secara efektif dan efisien dalam membantu terwujudnya tujuan".

Pada awal terbentuknya unit perpustakaan IPDN hanya ada tenaga teknis perpustakaan dan 
belum ada pustakawan, oleh sebab itu pada tahun 1996 empat orang tenaga teknis perpustakaan yang berstatus PNS mengikuti Diklat Perpustakaan. Dari empat orang tersebut hanya dua orang yang tetap bertugas di unit perpustakaan dan yang lainnya dipindahkan ke unit lain, hal ini dilakukan agar tujuan perencanaan sumber daya manusia tercapai. Sesuai dengan teori Hasibuan, M (2017:250) sebagai berikut:

1) Untuk menentukan kualitas dan kuantitas karyawan yang akan mengisi semua jabatan dalam perusahaan.

2) Untuk menjamin tersedianya tenaga kerja masa kini maupun masa depan, sehingga setiap pekerjaan ada yang mengerjakannya.

3) Untuk menghindari terjadinya mismanajemen dan tumpeng tindih dalam pelaksanaan tugas.

4) Untuk mempermudah koodinasi, integrase dan sinkronisasi (KIS) sehingga produktivitas kerja meningkat.

5) Untuk menghindari kekurangan atau kelebihan karyawan.

6) Untuk menjadi pedoman dalam menetapkan program penarikan, seleksi, pengembangan, kompensasi, pengitegrasian, pemeliharaan, kedisiplinan dan pemberhentian karyawan.

7) Menjadi pedoman dalam melaksankan mutase (vertikal atau horizontal) dan pensiun karyawan.

8) Menjadi dasar dalam melakukan penilaian karyawan.

2) Optimalisasi SDM dalam implementasi manajemen pengetahuan (knowledge management)

Optimalisasi SDM di perpustakaan IPDN adalah dengan mengikuti pelatihan, sosialiasi dan diklat tentang Ilmu Perpustakaan dan Teknologi Informasi di dalam ataupun diluar IPDN atas perintah pimpinan ataupun mandiri bahkan melajutkan pendidikan ke jenjang yang lebih tinggi.

Menurut pustakawan senior, pada awal terbentuknya unit perpustakaan IPDN hanya ada tenaga teknis perpustakaan dan belum ada pustakawan, oleh sebab itu pada tahun 1996 empat orang tenaga teknis perpustakaan yang berstatus PNS mengikuti Diklat Perpustakaan. Dari empat orang tersebut hanya dua orang yang tetap bertugas di unit perpustakaan dan yang lainnya dipindahkan ke unit lain.

Kemudian atas kesadaran pribadi pada tahun 2001 tenaga teknis perpustakaan yang telah mengikuti diklat perpustakaan, melanjutkan pendidikan ke jenjang sarjana dan pasca sarjana jurusan ilmu perpustakaan untuk memajukan perpustakaan IPDN. Setelah mengikuti serangkaian pendidikan perpustakaan baik secara formal maupun diklat, pada tahun 2006 akhirnya ada satu orang pustakawan di perpustakaan IPDN. Hal ini sesuai dengan kepentingan perencanaan sumber daya manusia menurut Mangkunegara, A (2017:5) yaitu kepentingan individu; perencanaan sumber daya manusia sangat penting bagi setiap individu pegawai, karena dapat membantu meningkatkan potensinya, begitu pula kepuassan pegawai dapat dicapai melalui perencanaan karir.

Setelah ada satu orang pustakawan, kemudian ada akreditasi perguruan tinggi dan ternyata nilai akreditasi perguruan tinggi dari aspek jumlah pustakawan di perguruan tinggi memiliki bobot yang tinggi sedangkan perpustakaan IPDN hanya memiliki satu orang pustakawan, tentunya hal itu sangat kurang bagi penilaian akreditasi. Oleh sebab itu, pustakawan IPDN berinesiatif menyarankan rekan-rekanya di perpustakaan IPDN untuk melanjutkan kuliah di jurusan ilmu perpustakaan dan akhirnya ada dua orang tenaga teknis perpustakaan yang lainnya mulai kuliah jurusan perpustakaan dan setelah lulus mereka menjadi pustakawan, karena pada saat itu untuk menjadi pustakawan masih mudah sehingga cukup dengan melanjutkan pendidikan saja dan mengajukan diri ke bagian kepegawaian untuk menjadi pustakawan otomatis SK di kepegawaian keluar dan berpindahlah status kepegawaian dari tenaga teknis perpustakaan menjadi pustakawan, sehingga jumlah pustakawan di perpustakaan IPDN Jatinangor ada tiga orang. Selain untuk kepentingan individu hal ini juga dilakukan untuk kepentingan organisasi untuk mendapat calon pegawai yang memenuhi kualifikasi dan dapat dipersiapkan calon-calon pegawai yang berpotensi untuk menduduki posisi yang tepat (Mangkunegara, A, 2017:5).

Karena minimnya pustakawan di perpustakaan IPDN, maka pada tahun 2013 tenaga perpustakaan IPDN bagian keuangan menganggarkan biaya Diklat CPTA (Calon Pustakawan Tingkat Ahli), untuk 15 orang tenaga teknis perpustakaan IPDN Jatinangor ditambah dengan tenaga perpustakaan IPDN kampus regional untuk mengikuti diklat selama 3 bulan (628 jam) maka diadakanlah MOU dengan Perpustakaan Nasional melalui Perpustakaan Daerah Jawa Barat untuk pelaksanaan Diklat. Karena dalam Pasal 31-35 Peraturan Pemerintah Republik Indonesia Nomor 24 Tahun 2014 tentang 
Pelaksanaan Undang-undang Nomor 43 Tahun 2007.

Berdasarkan peraturan tersebut, maka tenaga teknis perpustakaan IPDN yang memenuhi persyaratan mereka lulus dan mengumpulkan berkas-berkas untuk penyesuaian menjadi pustakawan mereka menjadi pustakawan pada tahun 2015, sehingga pustakawan di perpustakaan IPDN sebanyak 18 orang yang bertugas di perpustakaan Jatinangor dan perpustakaan regional. Hal ini sesuai dengan teori komponenkomponen perencanaan sumber daya manusia menurut Mangkunegara, A (2017:5) yaitu: 1) tujuan (individu, organisasi atau nasional), 2) perencanaan organisasi; mengadakan perubahan yang positif, 3) pengauditan sumber daya manusia; penelusuran secara normal dan sistematis mengenai efektivitas program kepegawaian, program analisis jabatan, penarikan pegawai, pelatihan, promosi jabatan, pelayanan pegawai, gaji dan penelitian pegawai.

Seiring berjalannya waktu, perkembangan perpustakaan IPDN semakin berkembangnya yakni dari beralihnya dari manual ke digital, hal ini dilakukan menunjang pelayanan, perpustakaan Perguruan Tinggi pada saat ini sudah menggunakan Teknologi Informasi dan Komunikasi untuk memenuhi pelayanan yang baik agar cepat dan tepat waktu. Perpustakaan IPDN yang berbasis teknologi informasi dan komunikasi (TIK) mulai memakai prosedur kerja berbasis komputer dan sumber daya berbasis TIK untuk referensi. Sesuai dengan teori perpustakaan berbasis teknologi informasi/berbasis TIK menurut Borgman dalam Teed (2005) disebutkan bahwa :

'Libraries are set of electronic resources and associated technical capabilities for creating, searching and using information. In this sence they are an extension and enhancement of information storage and retrieval systems that manipulate berbasis TIK data in any medium (text, images, sounds ...) and exist in distributed networks'.

(Perpustakaan berbasis TIK adalah kumpulan sumber daya elektronik dan kemampuan teknis terkait untuk membuat, mencari dan menggunakan informasi. Dalam pengertian ini, mereka adalah perluasan dan peningkatan penyimpanan informasi dan sistem pengambilan yang memanipulasi data berbasis TIK dalam media apa pun (teks, gambar, suara...) dan ada dalam jaringan terdistribusi).
Kelebihan perpustakaan berbasis TIK sebagaimana Arms dalam Abdurahman Saleh (2014) adalah sebagai berikut : (1) perpustakaan berbasis TIK membawa perpustakaan ke pengguna (2) komputer dapat dimanfaatkan untuk mengakses dan menjelajah (browsing). (3) Informasinya dapat digunakan secara bersama (sharing), (4) informasi yang ada mudah untuk diperbarui (diupdate), (5) informasi selalu tersedia sepanjang hari, sepanjang masa, sepanjang hayat dan memungkinkan bentuk informasi baru.

Sedangkan kelebihan perpustakaan berbasis TIK dibandingkan dengan perpustakaan konvensional sebagaimana lebih lanjut diungkapkan Saleh (2014) adalah sebagai berikut (1) menghemat ruangan (2) akses ganda (multiple access), (3) tidak dibatasi oleh ruang dan waktu, (4) koleksi dapat berbentuk multimedia dan (5) biaya lebih murah. Berdasarkan teori-teori tersebut akhirnya perpustakaan IPDN bertranformasi menjadi perpustakaan berbasis TIK.

Oleh sebab itu, tenaga perpustakaan IPDN pun mau tidak mau harus mengikuti perkembangan tersebut untuk meningkatkan pelayanan prima bagi pemustaka. Hal ini sesuai dengan Buku Pedoman Umum Penyelenggaraan Perpustakaan Perguruan Tinggi tentang macammacam pola struktur organisasi perpustakaan (2004:6):

Tenaga teknis perpustakaan terdiri atas tenaga teknis komputer, tenaga teknis audio visual, tenaga teknis ketatausahaan, tenaga teknis asisten perpustakaan, dan/atau tenaga teknis lainnya. Administrasi layanan dilaksanakan untuk semua jenis kegiatan layanan perpustakaan. Administrasi Layanan Perpustakaan diselenggarakan untuk tujuan memudahkan dan menjamin pelaksanaan kerja secara efektif dalam Tenaga layanan. Administrasi Layanan Perpustakaan mengikuti pola dan cara yang baku atau yang berlaku dalam organisasi badan induknya. Administrasi Layanan Perpustakaan merupakan bukti pertanggungjawaban dalam pelaksanaan tugas layanan.

Kemudian, dalam Peraturan Kepala Perpustakaan Nasional Republik Indonesia Nomor 13 Tahun 2017 tentang Standar Nasional Perpustakaan Perguruan Tinggi halaman 10 disebutkan hal sebagai berikut: "Struktur 
organisasi Perpustakaan Perguruan Tinggi mencakup kepala perpustakaan, pelayanan pemustaka, pelayanan teknis, teknologi informasi dan komunikasi serta tata usaha".

Dengan adanya perubahan tersebut, maka pada tahun 2013 ada rekruitmen tenaga teknis perpustakaan bagian TIK untuk bertugas mengelola sistem informasi manajemen perpustakaan, karena perpustakaan berbasis teknologi informasi dan komunikasi merupakan kumpulan koleksi sumber elektronik (e-resources) yang memungkinkan aktivitas untuk penciptaan, penelusuran dan akses sumber elektronik. Kemudian dalam upaya pengembangannya dalam penyimpanan, penelusuran informasi serta media teks, gambar, suara atau gambar yang dapat didistribusikan melalui jaringan (networks). Oleh sebab itu, perpustakaan IPDN Jatinangor bekerja sama dengan UPTIK (Unit Pelayanan Teknologi Informasi) IPDN, untuk merekrut tenaga teknis bagian TIK, maka 1 pegawai UPTIK lulusan jurusan komunikasi dan perpustakaan diminta berpindah tugas ke unit perpustakaan meskipun bukan jurusan yang tepat untuk mengelola perpustakaan berbasis TIK, namun setidaknya memiliki latar belakang pengetahuan tentang teknologi informasi, karena dalam Pasal 32 Peraturan Pemerintah Republik Indonesia Nomor 24 Tahun 2014 tentang Pelaksanaan Undangundang Nomor 43 Tahun 2007.

\section{3) Pengembangan institusi dan tenaga perpustakaan}

Seiring berjalannya waktu, perkembangan perpustakaan semakin berkembangnya yakni dari beralihnya dari manual ke digital, sehingga tenaga perpustakaan IPDN pun mau tidak mau harus mengikuti perkembangan tersebut untuk meningkatkan pelayanan prima bagi pemustaka.

Menurut Hasibuan, M (2017:70). tujuan pengembangan hakikatnya menyangkut hal-hal berikut: Produktivitas kerja; dengan pengembangan produktivitas kerja karyawan akan meningkat, kualitas dan kuantitas produksi semakin baik, karena technical skill, human skill dan managerial skill karyawan yang semakin baik.

Dengan adanya perubahan tersebut, maka pada tahun 2013 ada rekruitmen tenaga teknis perpustakaan bagian TIK untuk bertugas mengelola sistem informasi manajemen perpustakaan. Oleh sebab itu, perpustakaan IPDN Jatinangor bekerja sama dengan UPTIK (Unit Pelayanan Teknologi Informasi) IPDN, untuk merekrut tenaga teknis bagian TIK, maka 1 pegawai UPTIK lulusan jurusan komunikasi dan perpustakaan diminta berpindah tugas ke unit perpustakaan meskipun bukan jurusan yang tepat untuk mengelola perpustakaan berbasis TIK, namun setidaknya memiliki latar belakang pengetahuan tentang teknologi informasi.

Meskipun bukan jurusan yang tepat, tetapi karena kemauan individu tenaga teknis yang ingin belajar dan meningkatna kompetensinya baik secara otodidak maupun mengikuti pelatihan seperti diklat pranata komputer dan bergabung dengan komunitas tenaga teknis perpustakaan perguruan tinggi di wilayah Jawa Barat, sehingga tenaga teknis bagian TIK banyak belajar tentang teknis perpustakaanan. Dukungan dari pimpinan dan tenaga perpustakaan yang lain pun sangat berpengaruh pada motivasinya untuk selalu belajar hal-hal yang baru.

Pada tahun 2016 tenaga perpustakaan IPDN Jatinangor mendapat penawaran untuk Diklat CPTA (Calon Pustakawan Tingkat Ahli) dari Perpustakaan Nasional secara gratis, maka kepala uinit perpustakaan IPDN mengirimkan enam orang tenaga teknis perpustakaan untuk mengikuti Dikla CPTA, setelah selesai pada tahun 2017 mereka menjadi pustakawan dan akhirnya Perpustakaan IPDN mempunyai pustakawan dari jalur Pendidikan S1 Ilmu Perpustakaan sebanyak tiga orang kemudian yang dari jalur Diklat 20 orang, sehingga jumlah 24 orang yang sudah menduduki jabatan pustakawan sesuai jenjang jabatan yang bertugas di perpustakaan IPDN Jatinangor dan perpustakaan IPDN regional.

Pada bulan Desember 2017 ada peraturan inpassing fungsional pustakawan, banyak sekali PNS di lingkungan IPDN yang mendaftar. Pada tahun 2018 mereka mengikuti tes, akhirnya pada tanggal 16 Januari 2020 ada keputusan MENPAN No. 92020 tentang Penetapan Penyesuain Inpasing Pustakawan dan dinyatakan sebanyak 29 orang lulus inpassing fungsional pustakawan, sehingga jumlah pustakawan di perpustakaan IPDN Jatinangor dan kampus regional sebanyak 52 orang pustakawan, tetapi pustakawan yang bertugas di perpustakaan IPDN Jatianngor hanya 15 orang dan yang lainnya di perpustakaan IPDN yang lain.

Kemudian, dengan adanya kebijakan publikasi ilmiah dari Dikti pada tahun 2017, pustakawan yang sedang melanjutkan kuliah S2 mendapat kewajiban hal sama, sedangkan di perpustakaan IPDN belum ada wadah untuk publikasi ilmiah secara online, oleh sebab itu pustakawan mencari informasi untuk publikasi ilmiah dan banyak belajar dari komunitas- 
komunitas jurnal dan pustakawan perguruan tinggi di Jawa Barat.

Pada awalnya pustakawan bergabung dengan komunitas Relawan Jurnal Indonesia (RJI) dan banyak belajar mengenai manajemen penulisan karya ilmiah sampai cara publikasi, setelah mengetahui hal-hal tersebut pustakawan mulai menulis artikel ilmiah kemudian publikasi di ejournal Universitas Galuh. Menyadari pentingnya manajemen penulisan karya ilmiah dan publikasi maka pustakawan tersebut memilih menjadi pustakawan bagian TIK untuk mengembangkan layanan perpustakaan IPDN yang berbasis TIK seperti website, e-resource, ebooks, ejournal, repositori, pengecekan plagiarism dan laporan akhir praja. Maka mulailah pustakawan IPDN dan bekerjasama dengan pihak terkait untuk membuat ejournal IPDN yang sampai saat ini sudah berjumlah 18 ejournal yang sudah terakreditasi SINTA dan belum terakreditasi.

Meskipun bukan berlatar belakang pendidikan ilmu perpustakaan, karena lulusan dari ilmu pemerintahan tetapi pustakawan bagian TIK selalu meningkatkan kompetensinya atas dasar kemauan pribadi dengan cara mengikuti pelatihan, seminar, bergabung pada komunitas Relawan Jurnal Indonesia (RJI) agar mendapat bimbingan dalam mengelola open journal system (OJS) dan hal-hal yang terkait dengan penulisan karya ilmiah sampai publikasinya.

Selain mengikuti pelatihan ataupun seminar, pustakawan bagian TIK pun mengembangkan kompetensinya dengan sharing knowledge kepada pemustaka seperti: praja dan Dosen sekaligus sebagai bentuk pelayanan prima pustakawan dengan cara mengadakan pelatihan atau workshop penulisan karya tulis ilmiah, sitasi dan lainnya di perpustakaan IPDN Jatinangor.

Menurutnya, ketika membagi pengetahuan tersebut ilmu yang dimiliki bukannya berkurang tetapi bisa bertambah karena tentunya tiap sesi workshop tenaga perpustakaan terlebih dahulu mempelajari materi-materi yang akan diseminarkan, selain itu ketika mengundang narasumber dari luar perpustakaan seperti: Dosen, peneliti, pegawai Perpusnas ataupun anggota komunitas pustakawan dapat saling berbagi pengetahuan/ sharing knowledge.

Selain sebagai pustakawan bagian TIK pun merangkap sebagai editor in chieve ataupun manager journal pada ejournal IPDN, sehingga lebih leluasa saat sharing knowledge, karena selain memberikan pelatihan karya tulis ilmiah bagi praja, tetapi juga sebagai pengelola ejournal IPDN dan tentunya hal tersebut memudahkan pendampingan bagi para praja untuk menulis karya tulis ilmiah karena bisa berkomunikasi langsung mulai dari pendampingan penulisan sampai publikasi.

Dalam hal pengembangan institusi dan tenaga perpustakaan IPDN telah melaksanakan kegiatan pelatihan setiap tahunnya baik di dalam atau luar lingkungan perpustakaan IPDN kurang lebih 1-3 kali pelatihan setiap tahunnya,seperti: Pelatihan Pelayanan Prima dan Pengembangan Diri bagi Tenaga Teknis Perpustakaan IPDN pada tanggal 26-27 September 2019, Pelatihan Lanjutan Pengolahan Bahan Pustaka Bagi Tenaga Teknis Perpustakaan IPDN Kampus Pusat dan Daerah, Digitalisasi dan Katalogisasi Laporan Akhir, Skripsi Serta Hasil Penelitian Dosen Di Unit Perpustakaan IPDN Jatinangor, Pelatihan Public Speaking and Communication Skill Bagi Tenaga Teknis Perpustakaan IPDN Kampus Jatinangor dan Kampus Daerah. Pada pandemic covid 19 pun tenaga perpustakaan IPDN tetap semangat meningkatkan kompetensinya walaupun tidak ada pelatihan secara langsung, namun banyak juga pelatihan-pelatihan yang dilakukan secara virtual.

Pada masa pandemic covid 19 seperti ini, tenaga perpustakaan IPDN lebih mudah lagi mengikuti seminar-seminar ataupun pelatihan karena banyak webinar yang sifatnya daring, dalam satu hari ada yang 1-3 kali webinar perpustakaan, yang informasinya di didapatkan dari whatsapp grup Pustakawan Perguruan Tinggi Jawa Barat kemudian informasinya bisa dishare ke grup tenaga perpustakaan IPDN sehingga para pustakawan lebih mudah mendapat pengetahuan tentang perpustakaan hal ini juga didukung oleh fasilitas zoom premium dan google meet perpustakaan IPDN dengan 2 opsi meet meskupun baru ada 250 titik x 4 jadi 10.000 dan bisa diikuti 10.000 peserta serta fasilitas zoom premium dengan kapasitas 500 perserta.

Selain pelatihan ada juga Benchmarking dan Short Course Perpustakaan IPDN ke perpustakaan UGM diikuti sebanyak 45 orang dari Tim IPDN diterima oleh Kepala Perpustakaan UGM.

\section{4) Knowledge Identification (identifikasi pengetahuan) \\ Jenis-jenis pengetahuan/knowledge} menurut Polayi (1967) yang dikutip oleh Prasetya (2014) bahwa pengetahuan dibagi menjadi dua yaitu pengetahuan tacit dan explicit, yaitu:

1) Pengetahuan Implisit (Tacit Knowledge). 
Pengetahuan implisit adalah pengetahuan yang berada di dalam pikiran manusia yang tidak dinyatakan dalam bentuk tulisan, melainkan sesuatu yang terdapat dalam benak orang-orang yang bekerja di dalam suatu organisasi. Pengetahuan implisit berupa wawasan (insights), gerak hati (intuitions), dan firasat (hunches) yang sulit diungkapkan dan dibagi kepada orang lain. Pengetahuan implisit bersifat subyektif, intuisi, terkait erat dengan aktivitas dan pengalaman individu serta idealisme, values, dan emosi. Dalam hal ini tenaga perpustakaan IPDN sebagai bagian dari organisasi tentunya memiliki tupoksi kerja masing-masing hal tersebut lambat laun berpengaruh pada budaya kerja bagian masing-masing misalnya, bagian layanan sirkulasi tentunya jika hal tersebut dilakukan secara rutin dan berjalan tahunan, hal tersebut menjadi keahlian bagian sirkulasi dan jika ada pegawai baru tentunya orang yang ahli akan dijadikan tutor untuk membimbing. Hal ini sejalan dengan pendapat Menurut Nonaka (1995): 'Pengetahuan implisit memiliki dua dimensi. Yang pertama adalah dimensi teknis dan yang kedua adalah dimensi kognitif'.

2) Pengetahuan Eksplisit (Explicit Knowledge)

Pengetahuan eksplisit adalah pengetahuan yang telah dinyatakan dalam bentuk data, formula, spesifikasi produk, manual, prinsip-prinsip umum dan sebagainya. Pengetahuan eksplisit tertuang dalam media tercetak seperti buku, koran, jurnal, laporan penelitian, majalah, dan media elektronik seperti internet, e-Book, online journal, dan lain-lain.

Dalam hal ini tentunya dibutuhkan proses untuk mendapatkan pengetahuan-pengetahuan, tenaga perpustakaan sebagai sumber daya utama dalam manajemen pengetahuan di perpustakaan tentunya melakukan kegiatan-kegiatan agar pengetahuan tetap ada. Semua proses manajemen pengetahuan di perpustakaan IPDN identik dengan kegiatan rutin di perpustakaan. Menurut Debowski dalam dalam Hendrawan, R (2019:7): "Proses membantu untuk mengeksternalisasi pengetahuan (pengetahuan tasit menjadi eksplisit) yang berhubungan dengan perubahan proses kerja, organisasi dan sebagainya. Proses merupakan pengaturan dan deretan dari strategi, prinsip, nilai serta praktik untuk memastikan bahwa manajemen pengetahuan dapat berjalan baik ketika diimplementasikan.
(2019:8)

Menurut Probst dalam Hendrawan

'Untuk mengelola pengetahuan organisasi perlu dilakukan pengelompokkan dan kategorisasi masalah yang ditemui pada pada organisasi tersebut. Proses inti manajemen pengetahuan dikategorikan menjadi enam bagian, hal ini ditunjukkan agar peranan manajer atau pimpinan mampu mengotimalkan aktivitas pengetahuan dimulai dari individu ke seluruh ranah organisasi'.

Core Process Knowledge Management dikategorikan menjadi enam bagian, hal ini ditujukan agar peranan manajer mampu mengoptimalkan aktifitas Knowledge di dalam area individu ke seluruh area organisasi.

Proses manajemen pengetahuan (knowledge management) yang pertama adalah knowledge identification. Pengetahuan yang ada di perpustakaan biasanya sesuai dengan karya yang ditulis Dosen-Dosen berdasarkan basic pendidikan dan tugas mengajar agar linear dengan tujuan terpenuhinya tugas Tridharma dan tenaga perpustakaan yang nantinya akan mengklasifikasikan karya-karya Dosen maupun praja dan mahasiswa pascasarja seperti LA/Skripsi, Tesis maupun Disertasi sesuai dengan fakultas masing-masing. Tenaga teknis bagaian TIK menyiapkan repositorynya sebagai rumah untuk mereka menguplod untuk kepentingan praja, kelulusan, dan Dosen untuk kepangkatan.

Para Dosen atau pelatih biasanya menulis atas kesadaran pribadi baik itu yang sesuai dengan mata kuliah atau mata pelatihan yang diampu, setelah itu tenaga teknis perpustakaan menfasilitasi kerjasama penulis dengan penerbit yang biasa bermitra dengan perpustakaan IPDN. Setelah terbit, biasanya tenaga teknis perpustakaan memprioritasnya buku-buku hasil tulisan Dosen untuk diajukan ke bagian pengadaan sehingga bisa dibeli oleh perpustakaan IPDN sebanyak 20-50 eksemplar.

Penetapan SDM dalam identifikasi pengetahuan sesuai dengan kemampuannya ada yang di bidang Teknologi dan ada yang bagian teknisnya, seperti bidang otomasi, bidang pengolahan, pelayanan, seandainya ada pelatihan yang sekiranya membutuhkan bidang otomasi atau IT yang di berangkatkan mereka yang ahli di bidang itu, dan pulang dari pelatihan mengajarkan kepada rekan- rekan yang lain. 
Dalam mengidentifikasi pengetahuanpengetahuan pustakawan membagi berdasarkan literature primer dari hasil penelitian yang melaui review mendalam yang publikasinya memang berdasarkan review. Untuk literature abu-abu kita ada Laporan Akhir, Skripsi, Tesis, Disertasi walaupun di perpustakaan besar ini hanya menangani Skripsi dan Laporan Akhir, karena untuk Tesis dan Disertasi ada perpustakaan pascasarjana yang menanganinya. Tetapi ada juga yang mengirim kesini (perpustakaan pusat). Untuk LA dan skripsi tidak semua dimasukan ke repository karena dilema juga ketika edaran Dikti harus fulltext tetapi tahun lalu saja kita share ke praja harus fulltext hanya beberpa praja yang berani submit selebihnya hanya abstrak atau ringkasan saja. Karena riskan jika terjadi sesuatu pasti akan menimbulkan kehebohan yang luar biasa.

\section{5) Knowledge acquisition (pengadaan pengetahuan) \\ Proses manajemen pengetahuan} (knowledge management) yang kedua adalah knowledge acquisition (pengadaan pengetahuan). Pengadaan pengetahuan dilakukan dengan cara para tenaga perpustakaan di berikan pelatihan Turnitin, anti plagiarism, pelatihan $e$-jurnal dan $e$ book, pelatihan OJS (online jurnal system) dan pelatihan otomasi perpustakaan.

Dalam hal mengadakan pengetahuan pustakawan dan tenaga teknis bagian IT menyiapkan berdasarkan request kebutuhan pemustaka, selain diskusi tentang keilmuan yang sedang tren mereka juga menyebar kuisioner, atau ada ide-ide sendiri dari pustakawan, sebagai tim IT hanya sekedar mengimplementasikan apa-apa yang dibutuhkan, karena eprint itu ada, ecatalog ada yang lain ada ya karena kebutuhan-kebutuhan dari pemustaka. Seperti Dosen membutuhkan platform untuk karya ilmiah dan nantinya berhubungan dengan kepegawaian dan kepangkatan mereka, maka kita siapkan aplikasinya, praja dan mahasiswa pasca membutuhkan jurnal untuk mempublish jurnal mereka maka tim IT siapkan, jadi apa yang dibutuhkan maka kita langgan eresource.

Kemudian untuk pengelolaan buku ada OPAC, elibrary, dahulu perpustakan IPDN pakai Senayan untuk menginput data buku baik fisik maupun elektronik, yang fisik hanya data-data pustaka nya saja. Kalau digital ada ER (electronic resource), menyiapkan database local yang bisa diakses melalui website di er.ipdn.ac.id apabila ada data buku tapi yang hanya bisa dibuka di melalui area local network dan ada ruangan yang disediakan komputer untuk membaca buku secara online, tapi hanya local area saja (praja harus datang ke perpustakaan).

Selain itu juga ada ebook dan ejournal, sistemnya berlanggan setiap tahun bisa saja berubah langganan, biasanya berlanggan EBSCO, procest, Cambridge, dan ada petugas yangbbertugas mendownload itu lalu kita masukan ke ER, karena yang berlanggan biasanya sudah berakhir itu hanya bisa dilihat orang dalam perpustakaan IPDN saja, jadi untuk antisipasi disimpan di ER. Untuk gudang pengetahuan kita simpan di repository memakai aplikasi eprints untuk menyimpan hasil tulisan dosen, praja (skripsi/LA),pegawai (tutorial) untuk civitas akademika dan disiapkan untuk open source.

Open source telah siapkan server yang besar dari bagian UPTIK, flotting, folder, untuk yang berlanggan diadakan rapat per 6 bulan, dibuat berdasarkan kebutuhan dosen, praja terkait keilmuan apa/ yang lebih spefisik melalui kuisioner tentang kebutuhan dosen dan praja, dan hasil kuisioner tersebut menjadi dasar kita untuk menyiapkan apa yang dibutuhkan jurnal/ buku/ subjek-subjeknya agar lebih leluasa sehingga perlu diperlebar servernya, untuk maintenance, karena eprints harus diupdate, elibrary juga harus diupdate. Untuk OPAC bagian dari elibrary (SENAYAN) disiapkan untuk katalog, laporan dan layanan adaya yang DAS, jadi 3 tampilan dalam 1 platform.

\section{6) Knowledge development (pengembangan pengetahuan)}

Proses manajemen pengetahuan (knowledge management) yang ketiga adalah knowledge development (pengembangan pengetahuan) untuk mengembangkan pengetahuan pustakawan mengikuti diklat-diklat seperti diklat penulisan karya ilmiah ataupun diklat lain yang berhubungan dengan perpustakaan dan teknologi informasi.

Setelah mengikuti pelatihan, kemudian terus berlatih contohnya setelah ada diklat penulisan karya ilmiah kami implementasikan membuat karya ilmiah sendiri dan disubmit ke $e$ journal Perguruan Tinggi lain lalu dipublish. Selain itu juga dengan mentransfer pengetahuan yang didapatkan ketika mengikuti pelatihan seperti melatih para pemustaka baik praja, karyawan dan Dosen cara penelusuran e-book, e-journal, cara memakai Turnitin dan bagaimana cara 
penelusuran katalog otomasi dan cara publish artikel jurnal.

\section{7) Knowledge sharing and distribution (distribusi dan berbagi pengetahuan) \\ Proses manajemen pengetahuan}

(knowledge management) yang keempat adalah knowledge sharing and distribution (distribusi dan berbagi pengetahuan) yaitu dengan cara sosialiasi, bedah buku, publish jurnal di luar kampus IPDN dan open acces bagi pencari pengetahuan dari luar perpustakaan IPDN.

Pustakawan melakukan sosialisasi kepada praja, untuk mengumpulkan hasil skripsi atau LA, Tesis atau Disertasi bagi mahasiswa yang kemudian akan disimpan dan disebar melalui aplikasi open resource yaitu repository dan open journal system (ejorunal.ipdn.ac.id) dan literature abu-abu (eprints) perpustakaan IPDN.

Knowledge utilization
penyimpanan pengetahuan)
Proses manajemen pengetahuan
(knowledge management) yang kelima adalah knowledge utilization (penyatuan/ penyimpanan pengetahuan) dengan cara mengembangkan otomasi pelayanan peminjaman, pengembalian, perpanjangan buku, peminjaman di tempat laporan akhir, pembuatan kartu anggota, mengembangkan OJS, mengembangkan e-book, e-jurnal dan repository.

Pustakawan tidak mengumpulkan pengetahuan secara langsung, tetapi praja upload sendiri, dan menekankan hal itu untuk syarat bebas pustaka, setelah mereka cek turnitin, tenaga perpustakaan bagian laporan akhir.

Hal ini juga sesuai dengan pendapat pustakawan bagian layanan, untuk mendapat surat bebas pustaka mereka harus submit abstrak LA/skripsi, cek turnitin ke bagian IT juga merupakan syarat untuk bebas pustaka setelah itu lolos baru bisa daftar sidang bahkan mengambil ijazah, jika hilang bisa difotocopy arsipnya.

Menyatukan pengetahuan yang berasal dari tugas akhir praja disatukan dalam satu drive tetapi masih internal IPDN dalam domain ipdn.ac.id dibackup yang sudah ada, karena jaringan yang ada terkadang naik turun, sehingga disimpan di drive. Dan untuk panduan bisa dilihat di eprins.ipdn.ac.id/2612.

\section{9) Knowledge retention (penyimpanan pengetahuan)}

Proses manajemen pengetahuan (knowledge management) yang keenam adalah Knowledge retention (penyimpanan pengetahuan).
Bahan cetak yang ada di bagian pengolahan langsung di otomasi yang akhirnya bisa di lihat di catalog otomasi yang bisa di lihat dari mana saja pada alamat http://elib.ipdn.ac.id/katalog.

Dalam upaya pengembangan e-resources, pustakawan perpustakaan IPDN Jatinangor telah melanggan ebook dan ejournal dari EBSCO dengan lebih dari 3690 judul electronic book (ebook) dan 3240 judul electronic journal (ejournal) berbahasa Inggris dengan kategori Political Science, Social Sciences, Law, Philosophy, dan lain-lain. Ebook dan ejournal ini dapat diakses melalui alamat: http://search.ebscohost.com/ diseluruh jaringan IPDN.

Apabila pemustaka diluar jaringan IPDN, pemustaka bisa memasukan user ID: ipdnlib dan password: Libr4ry_19. Dengan fitur yang dimiliki oleh ebsco, seluruh ebook dan ejournal yang sudah dilanggan dapat didownload oleh pemustaka dimanapun dan kapanpun dengan format file pdf.

Perpustakaan IPDN juga telah membuat aplikasi e-Reader berbasis local area network dimana aplikasi tersebut digunakan sebagai wadah ebook dan ejournal yang sudah didownload. Aplikasi ini dapat diakses melalui jaringan lokal IPDN dialamat: http://er.elib.ipdn.ac.id/ . Kemudian repositori perpustakaan menggunakan aplikasi eprints dapat dilihat dalam situs http://eprints.ipdn.ac.id. Repositori ini untuk menyimpan hasil tulisan Dosen, praja (skripsi/LA), tenaga (tutorial) untuk civitas akademika dan disiapkan untuk open source.

Dalam mengidentifikasi pengetahuan tacit, tentunya ini terlihat pada skill tiap tenaga perpustakaan berdasarkan tugas masing-masing pada setiap bagian layanan, hal tersebut jika dilakukan dalam rentan waktu yang lama tentunya akan menjadi kebiasaan dan menjadi pengetahuanpengetahuan baru, misalnya tenaga perpustakaan bagian layanan dan informasi website akan memiliki keahlian pada bidangnya, apalagi jika melihat hasil laporan kinerja dan karya tulis yang dibuat baik untuk kepentingan individu seperti kenaikan pangkat ataupun untuk kepentingan organisasi seperti untuk akreditasi, tentunya dengan skill dan knowledge yang dimiliki tenaga perpustakaan tersebut bisa menjadi pengetahuan baru bagi tenaga perpustakaan lainnya

Didalam pengidentifikasian explisit knowledge tenaga perpustakaan bagian pengadaan meilakukan analisis dan gambaran knowledge di lingkungan perpustakaan IPDN. Tenaga perpustakaan IPDN bagian pengadaaan memberikan survey kebutuhan pemustaka berupa 
daftar permintaan usulan bahan pustaka yang diperlukan oleh praja dan Dosen, kemudian hasil daftaran tersebut dicek kembali oleh bagian pengadaan misalnya buku apa saja yang dibutuhkan dan buku apa saja yang lebih lebih prioritas kemudian disesuaikan dengan ketersediaan pada katalog buku dari penerbit, setelah itu mengajukan ke bagian kelengkapan dan anggaran agar dapat direalisasikan, meskipun tidak semuanya langsung terealisasi karena keterbatasan anggaran.Tenaga perpustakaan IPDN selalu memprioritaskan buku yang ditulis oleh Dosen atau Pelatih IPDN, karena buku yang ditulis oleh Dosen atau pelatih akan dipakai dalam proses perkuliahan baik itu menulis buku wajib atau buku penunjang ataupun pelatihan. Proses pengadaaannya dengan cara mengkomunikasikan kepada Dosen penyediaan buku dan meprioritaskan buku karya Dosen.

Selain perencanaan bahan pustaka cetak, tenaga perpustakaan khususnya pustakawan bagian TIK juga melakukan kegiatan penciptaan pengetahuan atau bahan pustaka non cetak, namun sebelum itu biasanya diadakan sosialisasi terlebih dahulu kepada pemustaka akan adanya aplikasi perpustakaan IPDN yang mudah diakses asalkan ada perangkat PC atau dawai serta koneksi internet. Setelah sosialisasi perpustakaan berbasis TIK, kemudian pelatihan, pendampingan dan mengadakan call paper serta dipublikasikan di sistem perpustakaan yang berbasis TIK.

\section{0) Komunikasi}

Dalam implementasi manajemen pengetahuan tentunya teknologi dijadikan sarana untuk komunikasi tenaga perpustakaan dan pustakawan di perpustakaan IPDN untuk meningkatkan pelayanan prima bagi pemustaka. Oleh sebab itu lembaga menyiapkan jaringan internet dengan kapasitas baik dan aplikasiaplikasi perpustakaan berbasis teknologi.

Menurut Debowski dalam Hendarawan (2019:9): “ Teknologi merupakan peran pendukung yang penting dalam manajemen pengetahuan, dimana dibutuhkan individu yang kompeten dan terpercaya menggunakannya". Sedangkan menurut Dalkir dalam Hendrawan (2019:9) bahwa:

'Dalam implementasi system manajemen pengetahuan diperlukan berbagai alat yang cukup beragama untuk dapat ikut terlibat di sepanjang siklus manajemen pengetahuan dan teknologilah yang dapat menfasilitasi, terutama dalam hal komunikasi, kolaborasi dan manajemen konten yang bertujuan untuk menciptakan, mengoragnisasikan, mendesiminasikan, melestarikan hingga aplikasi untuk mengelola pengetahuan'.

Ketiga komponen manajemen pengetahuan tersebut saling berhubungan dan tidak bisa dipisahkan. Dalam membangun manajemen pengetahuan yang utuh mebutuhkan ketiga komponen tersebut. Orang sebagai penggerak pengetahuan berperan sebagai sumber pengetahuan sekaligus sebagai pengguna pengetahuan. Proses dilakukan untuk memastikan pengetahuan yang ada tetap tersedia pada saat dibutukan. Dan teknologi berperan sebagai fasilitator manajemen pengetahuan, dimana teknologi ini menjadi pintu bagi pengguna dalam menciptakan, mengorganisasikan, mengakses, menyebarluaskan dan melestarikan pengetahuan.

Hal ini juga selaras dengan pendapat Stankosky (2000), bahwa teknologi merupakan alat dalam mendukung manajemen pengetahuan dalam organisasi. penentuan dan pendefinisian kemampuan teknologi sangat penting dilakukan agar sesuai dan sejalan dengan kebutuhan organisasi.

Pada saat ini di kampus IPDN Jatinangor hampir semua gedung sudah terkoneksi dengan internet, koneksi internet antar gedung telah menggunakan media kabel Fiber Optic. Pemanfaatan Teknologi Informasi dan Komunikasi membantu perpustakaan memperbaiki kualitas dan jenis layanan. Minimal saat ini sebuah perpustakaan harus mempunyai: (1) Jaringan lokal (Local Area Network) berbasis TCP/IP. (2). Akses ke Internet. (3). Komputer untuk pustakawan dan pemakai perpustakaan. Harus ada komputer untuk server yang akan memberikan servis kepada pemakai, komputer untuk pustakawan bekerja dan komputer untuk pemakai agar bisa menggunakan layanan perpustakaan.

Adapun aplikasi dan resource perpustakaan IPDN terdiri atas: Portal Web Perpustakaan, Online Public Access Catalog (OPAC), Ebook dan ejournal, Repositori perpustakaan IPDN, dan Aplikasi Anti Plagiarisme

\section{1) Pengembangan teknologi manajemen pengetahuan}

Pembuatan aplikasi perpustakaan berbasis teknologi informasi di IPDN dimulai pada tahun 2012. Perpustakaan IPDN bekerjasama dengan Unit Pelayanan Teknologi Informasi IPDN dan pihak ketiga sebagai konsultan memutuskan untuk menggunakan aplikasi Senayan V3. Senayan atau lengkapnya Senayan Library Management System 
(SLiMS), adalah perangkat lunak sistem manajemen perpustakaan (library management system) sumber terbuka yang dilisensikan di bawah GPL v3. Aplikasi web yang dikembangkan oleh tim dari Pusat Informasi dan Humas Departemen Pendidikan Nasional Republik Indonesia ini dibangun dengan menggunakan PHP, basis data MySQL, dan pengontrol versi Git.

Pustakawan dan tenaga teknis IT menyiapkan aplikasi-aplikasi, untuk pengelolaan buku kita ada OPAC, elibrary. Dahulu memakai Senayan untuk menginput data buku baik fisik maupun elektronik, yang fisik hanya data-data pustaka nya saja. Kalau digital ada ER (electronic resource), tenaga perpustakaan menyiapkan database local yang bisa diakses melalui website di er.ipdn.ac.id disitu ada data buku tapi yang hanya bisa dibuka di melalui area local network dan ada punya ruangannya dan disediakan computer untuk membaca buku secara online, tapi hanya local area saja (pemustaka harus datang ke perpustakaan).

Perencanan teknologi di perpustakaan IPDN untuk meningkatkan pelayanan prima bagi pemustaka, tenaga perpustakaan sudah menyiapkan jaringan internet dengan kapasitas baik dan aplikasi-aplikasi perpustakaan berbasis teknologi. Aplikasi otomasi perpustakaan IPDN ini terdiri dari beberapa tampilan, yaitu tampilan untuk administrator dan tampilan anjungan untuk pemustaka dalam portal web prpustakaan IPDN http://app.elib.ipdn.ac.id/dash.

Kemudian untuk menjalankan fungsinya perpustakaan IPDN sesuai dengan Buku Pedoman Perpustakaan Perguruan Tinggi (2004:3) fungsi perpustakaan Perguruan Tinggi dapat ditinjau dari berbagai segi yaitu:

1. Fungsi Edukasi

Perpustakaan IPDN merupakan sumber belajar bagi sivitas akademika IPDN dengan menyediakan fasilititas eresource, untuk mendukung pembelajaran setiap program studi di kampus IPDN. Berdasarkan hasil laporan tahun 2020, perpustakaan IPDN Jatinangor memiliki 15.287 judul buku dengan 79.692 eksemplar, sehingga banyak pengetahuan yang dapat didapatkan pemustaka sebagai hasil implementasi manajemen pengetahuan di perpustakaan IPDN Jatinangor. Kemudian ada 10 macam rumpun ilmu yang menjadi koleksi perpustakaan IPDN Jatinangor, yaitu karya umum, ilmu filsafat, agama, ilmu-ilmu social, bahasa, ilmu murni, teknologi (terapan), kesenian, kesusatraan dan geografi umum dan sejarah, semua rumpun ilmu tersebut menurut peneliti memadai untuk menunjang kebutuhan pemustaka dalam implementasi manajemen pengetahuan di lingkungan kampus IPDN Jatinangor sebagai perguruan tinggi (sekolah kedinasan pemerintah). Kemudian bahan pustaka lain di perpustakaan IPDN Jatinangor juga yang bisa didapatkan pemustaka yaitu: ejournal, prosiding, laporan akhir (LA, Skripsi, Tesis dan Disertasi), CD/DVD, Laporan Hasil Kajian dan Penelitian, Menu/Literatur perkuliahan karya civitas akademika IPDN, Buku Karya Civitas Akademika IPDN, Buletin, Digital Book, majalah, Laporan rekomendasi LPM untuk menunjang kebutuhan pemustaka dalam implementasi manajemen pengetahuan di lingkungan kampus IPDN Jatinangor sebagai perguruan tinggi (sekolah kedinasan pemerintah).

\section{Fungsi Informasi}

Perpustakaan IPDN menjadi sumber informasi yang mudah diakses oleh pemustaka. Dengan adanya OPAC (Online Public Access Catalog), merupakan sarana penelusuran yang diperuntukkan bagi pemustaka yang bisa dibuka dimanapun dan kapanpun. Pencarian buku di OPAC dapat dipilih berdasarkan lokasi kampus. Pemustaka bisa menelusur dengan mengetikan keyword baik judul buku ataupun penulis buku di form pencarian. Tampilan sederhana OPAC IPDN dapat menampilkan ID buku, title (Jjudul buku), dan author (penulis buku) untuk memudahkan pemustaka didalam penelusuran buku cetak di perpustakaan IPDN. Tampilan ini dapat diakses melalui link: http://app.elib.ipdn.ac.id/katalog.

\section{Fungsi Riset dan Deposit}

Perpustakaan IPDN menyediakan bahanbahan riset sebagai bahan untuk melakukan penelitian dan pengkajian ilmu pemerintahan. Dalam upaya pengembangan e-resources, pustakawan perpustakaan IPDN Jatinangor telah melanggan ebook dan ejournal dari EBSCO dengan lebih dari 3690 judul electronic book (ebook) dan 3240 judul electronic journal (ejournal) berbahasa Inggris dengan kategori Political Science, Social Sciences, Law, Philosophy, dan lain-lain. Ebook dan ejournal ini dapat diakses melalui alamat: http://search.ebscohost.com/ diseluruh jaringan IPDN. Apabila pemustaka diluar jaringan IPDN, pemustaka bisa memasukan user ID: ipdnlib dan password: Libr4ry_19. Dengan fitur yang dimiliki oleh ebsco, seluruh ebook dan ejournal yang sudah dilanggan dapat didownload oleh pemustaka dimanapun dan kapanpun dengan format file pdf.

Perpustakaan IPDN juga telah membuat aplikasi e-Reader berbasis local area network 
dimana aplikasi tersebut digunakan sebagai wadah ebook dan ejournal yang sudah didownload sebelumnya dari berbagai agregator yang kami langgan diantaranya: mc grawhil, gale, cambridge, dan ebsco. Aplikasi ini dapat diakses melalui jaringan lokal IPDN dialamat: http://er.elib.ipdn.ac.id/ .

4. Fungsi Publikasi dan interpretasi

Perpustakaan IPDN sudah membantu melakukan publikasi karya yang dihasilkan oleh civitas akademika IPDN dengan melakukan pendampingan karya tulis ilmiah dan menyediakan 18 e-journal, repositori IPDN dan aplikasi pengecek plagiat turnitin.

Repositori perpustakaan IPDN menggunakan aplikasi eprints dapat dilihat dalam situs http://eprints.ipdn.ac.id. Repositori ini untuk menyimpan hasil tulisan Dosen, praja (skripsi/LA), tenaga (tutorial) untuk civitas akademika dan disiapkan untuk open source. Open source disiapkan server yang besar dari bagian UPTIK dan untuk yang berlanggan perpustakaan IPDN menyiapkan anggran per 6 bulan, dibuat berdasarkan kebutuhan Dosen dan praja terkait keilmuan apa yang dibutuhkan dan lebih prioritas. Kebutuhan tersebut diketahui sesuai dengan kuisioner yang telah disebar sesuai dan hasil kuisioner tersebut menjadi dasar kita untuk menyiapkan apa yang dibutuhkan jurnal/ buku/ subjek-subjeknya dan agar lebih leluasa diperlebar servernya setiap tahun untuk maintenance, dan aplikasi-aplikasi juga harus terus diupdate, seperti eprints dan elibrary.

Kemudian sebagai upaya mengatasi plagiarisme yaitu perbuatan menjiplak ide gagasan atau karya orang lain yang selanjutnya diakui sebagai karya sendiri atau menggunakan karya orang lain tanpa menyebutkan sumbernya, serta untuk melindungi civitas akademika IPDN dalam mengupload karya ilmiah, perpustakaan IPDN Jatinangor melanggan aplikasi antiplagiarisme Turnitin. Tenaga perpustakaan IPDN memberikan panduan kepada mahasiswa untuk mengunggah (upload) file pekerjaannya ke dalam situs tersebut sesuai dengan nama kelas dan jenis tugasnya setelah diberi kode kelas dan password kelas yang sudah dibuat oleh Dosen, kemudian Dosen akan mengecek orisinalitas dan kualitas pekerjaan tersebut. Peer-checking juga dapat diakses dari akun Turnitin.com pribadi masing-masing mahasiswa. Aplikasi ini dapat diakses melalui alamat: turnitin.com. Namun, mulai awal Maret 2020 karena keterbatan anggaran sehingga untuk sementara perpustakaan IPDN berhenti berlanggan Turnitin.

\section{PENUTUP}

Berdasarkan uraian tersebut dapat disimpulkan bahwa perencanaan implementasi manajemen pengetahuan di perpustakaan IPDN adalah sebagai berikut: Perencanaan tenaga perpustakaan IPDN Jatinangor dari segi rekruitmen, pendidikan, pengembangan, motivasi, retensi, kerjasama dan partisipasi seluruh pegawai (share knowledge to creating value through social interaction) sudah dilakukan meskipun belum maksimal, karena pustakawan bagian IT jumlahnya masih sedikit dan tenaga teknis IT juga belum ada ahlinya, sehingga pengelolaan website masih bekerjasama dengan unit lain di IPDN.

Perencanaan proses pengadaan pengetahuan dan teknologi di perpustakaan IPDN telah dilakukan oleh tenaga perpustakaan IPDN, walaupun tidak semua terealisasi karena keterbatasan anggaran.

\section{DAFTAR PUSTAKA}

Abbas, Syahrizal. (2014). Manajemen Perguruan Tinggi. Jakarta: Kencana Prenadamedia Group.

Badan Pengembangan dan Pembinaan Bahasa Kementrian Pendidikan dan Keebudayaan (2016). Pedoman Umum Ejaan Bahasa Indonesia.

Debowski, Shelda. (2006). Knowledge Management. Melbourne and Sydney: John Wiley and Son Australia, Ltd.

Dilip, Bhatt. (2000). "EFQM Excellence model and knowledge management implications." Published by EFQM Organization 8. http://www.eknowledgecenter.com/articles/ 1010/1010.htm. Diakses pada 20 Mei 2019.

Creswell, John W. (2012). Research Design Pendekatan Kualitatif, Kuantitatif, dan Mixed. Yogyakarta: Pustaka Pelajar.

Dalkir, K. (2005). Knowledge Management in Theory and Practice. Oxford, UK: Burlington, MA.

Darmawan, D. (2012). Pendidikan Teknologi Informasi dan Komunikasi. Bandung. PT Remaja Rosdakarya 
Davenport, T. De Long, and Beers, M. (1998). Succesful Knowledge Management Project. Sloan Management Review, 39(2), 43-57.

Davenport, TH and Prussak, L. (1988). Working Knowledge, Harvard Bussines School Press.

Davis, Keith. (2010). Organizational Behavior Human Behavior at Work 13th Edition. New Delhi: Mcgraw Hill Company.

Debowski, Shelda. (2006). Knowledge Management. Melbourne and Sydney: John Wiley and Son Australia, Ltd.

Departemen Pendidikan Nasional RI Direktorat Jenderal Pendidikan Tinggi. (2004). Perpustakaan Perguruan Tinggi Buku Pedoman. Jakarta.

Eneste, P (2017). Buku Pintar Penyuntingan Naskah. (Cet-3). Jakarta: Kompas Media.

Frappaolo, Carl dan Toms, Wayne. (1997). Knowledge management: from terra incognita to terra firma. http://www.delphigroup.com/articles/1997/ 11071997.

Terry, G.R . (1978). Principles of Management.Illinois: Richard D. Irwin Inc.

Galagan, P. (1997). Smart Companies (Knowledge Management). Training and Development, Vol 51, No 12, h 20-5.

Galbraith.J.,(1973), Designing Complex Organizations, Reading, Mass: AddisonWesley Publishing Company.

Hasibuan, M (2017). Manajemen Sumber Daya Manusia (Cet-17) Jakarta: PT Bumi Aksara.

Hendrawan, M. (2019). Manajemen Pengetahuan Konsep dan Praktik Berpengetahuan pada Organisasi Pembelajar. Malang: UB Press.

Ismail Nawawi, (2012). Manajemen Pengetahuan. Bogor. PT Ghalia Indonesia.
Laurence Prusak. (1998). Working Knowledge : How Organizations Manage What They Know. Harvard Business School Press, Boston.

Lasa HS. (2005). Manajemen Perpustakaan. Yogyakatra : Gama Media. Hlm 3.

Mangkunegara, A.A. (2017). Manajemen Sumberdaya Manusia Perusahaan. (Cet14).Bandung: PT. Remaja Rosdakarya.

Merriam-Webster. (2011). Keyword Definition. Merriam-Webster Online Dictionary. Retrieved July 9, 2011, from http://www.merriamwebster.com/dictionary/keyword.

Moleong, J.L (2019). Metodologi Penelitian (cet39). Bandung: Rosdakarya.

Nonaka, Ikujiro dan Hirotaka Takeuchi. (1995). The Knowledge-Creating Company: How Japanese Companies Create the Dynamic of Innovation. New York: Oxford University Press.

Nurul, I. (2015). Manajemen Pengetahuan Teori dan Praktik. Yogyakarta: Gajah Mada University Press.

Partridge, D. dan Hussain, KM. (1995). Knowledge-based information systems. London: McGraw-Hill Book Company.

Priansa, D (2017). Manajemen Pelayanan Prima Fokus pada Organisasi Publik dan Peningkatan Kualitass Aparatur. Bandung: Alfabeta.

Ranupandojo, H., dan Suad Husnan, (1990). Manajemen Personalia, Edisi III, Yogyakarta: BPFE.

Saleh, Abdul Rahman. (2014). Model Perpustakaan Digital di Indonesia Sebuah Usulan. Jakarta: Pusat Pengembangan Pustakawan Perpustakaan Nasional RI.

Sanusi, A. (2015). Sistem Nilai. Bandung: Nuansa Cendekia. 
Short, F.T dan C.M Duarte. (2001). Methods for the Measurement of Seagrass Growth and Production. 155-180 h. In F.T. Short dan R.G Coles (ed),Global seagrass research methods. Elsevier Science B.V. Netherlands.

Soeatminah. (1992). Perpustakaan, Kepustakawanan dan Pustakawan. Yogyakarta: Kanisius.

Soejono Trimo, M.L.S.( 1985). Pedoman Pelaksanaan Perpustakaan. Bandung: Remadja Karya Offset.

Sony Keraf dan Mikhael Dua. (2001). Ilmu Pengetahuan; Sebuah Tinjauan Filosofis. Yogyakarta; Kanisius,

Sukarna. (2011). Dasar -dasar Manajemen. Bandung: Mandar Maju

Sugiyono, (2016). Metode Penelitian Kombinasi. (Cet-8) Bandung: Alfabeta.

Sulistyo Basuki. (2003). Pengantar Ilmu Perpustakaan, Jakarta: Universitas Terbuka. Depdikbud.

Tafsir, A. (2017). Filsafat Ilmu Mengurai Ontologi, Epistimologi dan Aksiologi Pengetahuan, (Cet-10). Bandung: Rosdakarya.

Tobing, Paul L. (2007). Knowledge Management, Konsep Arsitektur dan Implementasi. Yogyakarta: Graha Ilmu.

Wallace, Danny P.(2007). Knowledge Management: Historical and Crossdisciplinary themes. USA: Libraries Unlimited.

Yusup, Pawit. (2012), Perspektif Manajemen Pengetahuan, Informasi, Komunikasi, Pendidikan dan Perpustakaan. Jakarta: PT. Rajagrafindo Persada.

Ya'qub, H (1984). Menuju Keberhasilan Manajemen dan Kepemimpinan. Bandung: CV Diponegoro. 